\title{
Phenotypic and Molecular Characterization of Staphylococcus xylosus: Technological Potential for Use in Fermented Sausage
}

\author{
Ângela Maria Fiorentini ${ }^{1,2}$, Maristela Cortez Sawitzki ${ }^{1,4}$, Teresinha Marisa Bertol ${ }^{3}$, Fábio \\ Cristiano Angonesi Brod ${ }^{1}$, Márcia Regina Pelisser ${ }^{1}$, Ana Carolina Maisonnave Arisi ${ }^{1 *}$ and \\ Ernani Sebastião Sant'Anna ${ }^{1}$ \\ ${ }^{I}$ Departamento de Ciência e Tecnologia de Alimentos; Centro de Ciências Agrárias; Universidade Federal de Santa \\ Catarina; Rod. Admar Gonzaga, 1346; 880034-00; Florianópolis - SC - Brasil .'2Departamento de Biologia e \\ Química; Universidade de Ijuí; RS 344, km 39; 98900-000; Santa Rosa - RS - Brasil. ${ }^{3}$ Embrapa Suínos e Aves; BR \\ 153, km 110; 89700-000; Concórdia - SC - Brasil. ${ }^{4}$ Universidade Estadual do Rio Grande do Sul; Rua Nelsis Ribas \\ Fritsch, 1111; 98200-000; Ibirubá - RS - Brasil
}

\begin{abstract}
Micrococcaceae strains are applied to fermented sausage as starter cultures, where several members of this family are naturally found. The aim of the present work was to isolate and characterize Staphylococcus xylosus from artisanal sausages produced in South Region of Brazil. From 89 isolates presenting catalase positive and coagulase negative activities, 25 strains were selected for phenotypic characterization. Nine strains identified as Staphylococcus xylosus by API-STAPH were evaluated for their nitrate reduction capacity, which showed satisfactory growth of the strains in the presence of nitrite and sodium chloride, demonstrating their potential for use as starter cultures in fermented sausage. The strains were also evaluated through genus and species-specific $P C R$, which showed only two as $S$. xylosus, differing from results found in phenotypic characterization.
\end{abstract}

Key words: Staphylococcus xylosus, fermented sausage, starter cultures, PCR

\section{INTRODUCTION}

Lactic acid bacteria (LAB) and Gram-positive catalase positive cocci (GCC+) (Micrococcaceae) are the most important bacteria found in meat sausages, for the manufacturing technology. They are used as starter cultures in meat products where $\mathrm{LAB}$ are responsible for producing lactic acid and then preventing the growth of pathogens. Micrococcaceae family, mainly Staphylococcus and Kocuria strains, are known for ensuring colour stability and preventing lipid oxidation in fermented meat products. Besides, these strains also influence the level of aromatic compounds due to their lipolytic and proteolytic activities (Talon et al., 2002; Aymerich et al., 2003; Spricigo and Pianovsky, 2005).

Several staphylococcal species have been isolated from fermented sausages. $S$. xylosus and $S$. saprophyticus strains were dominant in Greek fermented sausages (Samelis et al., 1998; Papamanoli et al., 2002; Drosinos et al., 2005). In

\footnotetext{
* Author for correspondence: arisi@cca.ufsc.br
} 
Spanish sausages, S. xylosus was the dominant species (Garcia-Varona et al., 2000). Aymerich et al (2003) identified S. xylosus, S. carnosus and $S$. epidermidis in low-acid chorizos. Staphylococcal flora was more diversified in Italian sausages, in which species such as $S$. xylosus , $S$. saprophyticus, $S$. equorum followed by $S$. warneri, $S$. epidermidis and $S$. lentus were identified (Coppola et al., 2000; Cocolin et al., 2001a, Rossi et al., 2001). In traditional French dry fermented sausages, dominant species were $S$. xylosus, $S$. carnosus, S. warneri and S. saprophyticus (Montel et al., 1992, 1996).

S. xylosus is used in meat industry as a starter culture for fermented sausages, as it ensures colour formation and contributes to aroma development (Martín et al., 2005). The most promising starter strains are those isolated from naturally fermented meat products, where they are well adapted and are the dominant population (Drosinos et al., 2005).

Isolation, identification and characterization of Micrococcaceae from artisanal meat products ensure its application as starter culture in sausages keeping its artisanal characteristic with controlled fermentation and ripening processes. It is an alternative of processing because allows a stable product at room temperature and the enzymatic reactions carried out by Micrococcaceae influence the typical flavour of naturally fermented sausages. However, characterization of such microorganisms is needed to ensure their safe using as starter cultures.

Identification of microflora from meat sausages using only phenotypic methods is insufficient for characterizing a microorganism as it may be uncertain (Blaiotta et al, 2003), due to a subjective and ambiguous interpretation of the colorimetric profile resulting from biochemical (sugar fermentation) tests (Quere et al, 1997). Due to this, molecular methods have been increasingly used in characterization procedures: randomly amplified polymorphic DNA-PCR analysis (Rossi et al., 2001; Martín et al., 2005), species-specific PCR (Aymerich et al., 2003; Morot-Bizot et al., 2003; Rantsiou et al., 2005), multiplex PCR (MorotBizot et al., 2003). Many typing methods have also been used to characterize staphylococci, such as pulse-field gel electrophoresis (PFGE) (Snopkova et al., 1994), denaturing gradient gel electrophoresis (DGGE) of 16S rRNA gene fragments (Cocolin, et al., 2001b; Rantsiou, et al., 2005 ) and amplification of the 16S-23S intergenic spacer region (Rossi et al., 2001; Blaiotta et al., 2003).

The aim of the present work was to isolate and characterize Staphylococcus xylosus from artisanal sausages produced in South Region of Brazil by means of phenotypic and molecular methods, as well as to characterize their technological potencial for use as starter cultures in fermented sausage.

\section{MATERIALS AND METHODS}

\section{Isolation of Micrococcaceae}

Wild strains of Micrococcaceae were isolated from thirty eight (38) samples of artisanal sausages collected in twenty one cities of South Region of Brazil. After removing the casing, $25 \mathrm{~g}$ of each sample were homogenized in $225 \mathrm{~mL}$ of $0.1 \%$ peptone water. Decimal dilutions were prepared and plated in BHI Agar (Brain Heart Infusion, Merck), incubated at $35^{\circ} \mathrm{C}$ for $48 \mathrm{~h}$ and then purified by streaking onto BHI Agar (Merck). Isolated strains were studied by cell morphology, Gram staining and catalase test for assuring their classification in Micrococcaceae family. Selected strains were stored at $-50^{\circ} \mathrm{C}$ in $\mathrm{BHI}$ broth (Merck) containing $20 \%$ glycerol (Merck).

\section{Phenotypic Characterization}

The isolates were subjected to coagulase production test using rabbit plasma in EDTA (Merck). API-STAPH (BioMerieux) galleries were also used. This system provides the following tests: urea production, arginine, n-acetylglucosamine, reduction of nitrate, acetoin and sugar fermentation (maltose, d-mannitol, dmannose, lactose, sucrose, raffinose, d-trehalose, d-xylose, d-glucose, d-fructose). As recommended by the manufacturer, the bacterial suspension was inoculated into the galleries and incubated at $36^{\circ} \mathrm{C}$ for $18-24 \mathrm{~h}$.

\section{Effect of temperature, $\mathrm{pH}$ and sodium chloride ( $\mathrm{NaCl}$ ) concentrations}

The effect of $\mathrm{pH}$ was tested by growth in BHI broth (Merck) adjusted for $\mathrm{pH}$ values of 5.0 and 5.5. Effect of different concentrations of $\mathrm{NaCl}$ on growth was evaluated in BHI broth (Merck) supplemented with 10 and $15 \% \mathrm{NaCl}$. Both testes were evaluated for growth ability at different temperatures: 15 and $45^{\circ} \mathrm{C}$. 
Tolerance to $\mathrm{NaCl}$ and sodium nitrite $\left(\mathrm{NaNO}_{2}\right)$ Tolerance to $\mathrm{NaCl}$ and $\mathrm{NaNO}_{2}$ was tested by growth on BHI agar supplemented with different $\mathrm{NaCl}\left(1.5,2.0,2.5\right.$, and 3.0\%) and $\mathrm{NaNO}_{2}(80$, $100,120,150$ and $200 \mu \mathrm{g} / \mathrm{g}$ ) concentrations and incubated at $35^{\circ} \mathrm{C}$ for $48 \mathrm{~h}$.

The simultaneous tolerance of strains to $\mathrm{NaCl}$ and $\mathrm{NaNO}_{2}$ was examined on BHI agar (Merck) supplemented with $\mathrm{NaCl}(3 \%)$ and $\mathrm{NaNO}_{2}(200$ $\mu \mathrm{g} / \mathrm{g}$ ) incubated at $35^{\circ} \mathrm{C}$ for $48 \mathrm{~h}$.

\section{Capacity to reduce nitrites}

The ability of strains to reduce nitrites was tested in BHI broth (Merck) pH 5.0, supplemented with 156 and $300 \mu \mathrm{g} / \mathrm{g}$ of $\mathrm{NaNO}_{2}$ and incubated at $35^{\circ} \mathrm{C}$ for $48 \mathrm{~h}$. The level of residual nitrite was measured by spectrophotometry at $474 \mathrm{~nm}$ (Harrigan and McCance, 1976).

\section{Lipolytic activity}

The lipolytic activity of strains was tested according to Kouker and Jaeger (1987) and Haba et al. (2000). The medium contained: $0.8 \%$ of nutrient broth (BBL); $0.4 \% \mathrm{NaCl} ; 1 \%$ of agaragar, was adjusted to $\mathrm{pH} 7$, autoclaved $\left(121^{\circ} \mathrm{C}\right.$ for $15 \mathrm{~min}$ ) and cooled at $60^{\circ} \mathrm{C}$. Then, a $2.5 \%$ final concentration of sterilized olive oil and $10 \mathrm{~mL}$ of Rhodamine B $(1 \mathrm{mg} / \mathrm{mL})$ dissolved in distilled water sterilized by filtration was added. After sonication, used by means of correct emulsification, the medium was spread onto Petri dishes. Lipase activity was identified on the plate as an orange fluorescent halo under UV light at $350 \mathrm{~nm}$ after $24-26 \mathrm{~h}$ of incubation at $37^{\circ} \mathrm{C}$.

\section{Molecular Characterization}

Isolated strains phenotypically characterized as Staphylococcus xylosus and reference strain ATCC 29971 were grown overnight in BHI broth at $35^{\circ} \mathrm{C}$. One milliliter $(\mathrm{mL})$ of each culture was centrifuged at $13,000 \mathrm{~g}$ for 2 minutes and DNA isolation was carried out from pellet cells by using the Wizard ${ }^{\circledR}$ Genomic DNA Purification Kit (Promega).

Amplifications were performed with the primers TstaG422/Tstag765 (Martineau et al., 2001) and XYLF/XYLR (Morot-Bizot et al., 2003; Corbiére Morot-Bizot et al., 2004) allowing the identification of the Staphylococcus genus and $S$. xylosus species, respectively. The TstaG422/Tstag765 and XYLF/XYLR amplify fragments of $370 \mathrm{bp}$ and $539 \mathrm{bp}$, respectively
(Morot-Bizot et al., 2003). Besides, a reference strain of Lactobacillus plantarum (ATCC 8014) was used as negative control in all PCR reactions. For molecular identification at genus level, PCR reactions were carried out in a final volume of 25 $\mu \mathrm{L}$ containing $2 \mu \mathrm{L}$ of extracted DNA, $2.5 \mathrm{mM}$ $\mathrm{MgCl}_{2}, \quad 0.2 \mu \mathrm{M}$ of each TstaG422/Tstag765 primers, $200 \mu \mathrm{M}$ of each dNTP and 1.25 U of Taq DNA polymerase in $1 \mathrm{x}$ buffer according to the manufacturer's instructions (Promega). Amplifications were performed in a Minicycler ${ }^{\mathrm{TM}}$ (MJ Research, Inc. Watertown, MA) under following conditions: $3 \mathrm{~min}$ at $96^{\circ} \mathrm{C}$, then 40 cycles of $30 \mathrm{~s}$ at $95^{\circ} \mathrm{C}, 60 \mathrm{~s}$ at $55^{\circ} \mathrm{C}, 30 \mathrm{~s}$ at $72^{\circ} \mathrm{C}$ and a final extension of $3 \mathrm{~min}$ at $72^{\circ} \mathrm{C}$ (MorotBizot et al., 2003; Martineau et al., 2001).

For molecular identification at species level, PCR reactions were carried out in a final volume of 25 $\mu \mathrm{L}$ containing $2 \mu \mathrm{L}$ of extracted DNA, $1.5 \mathrm{mM}$ $\mathrm{MgCl}_{2}, 0.2 \mu \mathrm{M}$ of each XYLF/XYLR primer, 200 $\mu \mathrm{M}$ of each dNTP and $1.25 \mathrm{U}$ of Taq DNA polymerase in $1 \mathrm{X}$ buffer according to the manufacturer's instructions (Promega). Amplifications were performed in a Minicycler ${ }^{\mathrm{TM}}$ (MJ Research, Inc. Watertown, MA) under following conditions: $5 \mathrm{~min}$ at $94^{\circ} \mathrm{C}$, then 40 cycles of $60 \mathrm{~s}$ at $94^{\circ} \mathrm{C}, 60 \mathrm{~s}$ at $55^{\circ} \mathrm{C}, 3 \mathrm{~min}$ at $72^{\circ} \mathrm{C}$ and a final extension of $6 \mathrm{~min}$ at $72^{\circ} \mathrm{C}$ (MorotBizot et al, 2003; Corbiére Morot-Bizot et al., 2004).

The PCR products $(10 \mu \mathrm{L}$ reaction $+2 \mu \mathrm{L}$ loading buffer) were separated through electrophoresis at $400 \mathrm{~mA}$ and $80 \mathrm{~V}$ for $50 \mathrm{~min}$ in $2.5 \%$ agarose gel, 1X TBE buffer and stained with ethidium bromide. The visualization was performed in UVtransilluminator and the images photographed with a digital camera (Canon Powershot A70).

\section{RESULTS AND DISCUSSION}

From a total of 175 Micrococcaceae strains isolated from naturally fermented sausages, 89 $(50.8 \%)$ were catalase-positive and coagulasenegative. API-STAPH system was used for phenotypic characterization of the isolated strains (Tables 1 and 2). Twenty-one $(84 \%)$ out of twenty-five strains were identified as Staphylococcus spp, one strain (4 \%) was identified as Kocuria varians and three (12\%) presented doubtful profile. Concerning to Staphylococcus identified strains, S. xylosus was 
the dominant species $(42.8 \%)$, followed by $S$. saprophyticus (28.5\%), S. lentus (19\%), S. epidermidis (4.7\%) and S. warneri (4.7\%). Papamanoli et al. (2002) found S. saprophyticus as the dominant species, followed by $S$. xylosus and $S$. carnosus in dry fermented sausage. Samelis et al. (1998) found that $S$. saprophyticus and $S$. xylosus dominated the Micrococcaceae populations in traditional Greek salami. These species occur in several regions of Europe and have been reported in some studies about isolation and phenotypic characterization of micrococci from meat products: S. saprophyticus (Seager et al, 1986; Coppola et al, 2000), S. epidermidis (Kotzekidou, 1992; Coppola et al, 2000) and S. xylosus (Miralles et al, 1996; Coppola et al, 2000). $S$. xylosus is the dominant species in most dry fermented sausages, being used as starter cultures because of its contribution to aroma and taste formation. Otherwise, S. saprophyticus and $S$. epidermidis are the dominant species found on human skin and are occasionally isolated from the skin of domestic animals. These species are probably acquired from the skin of pork or from human manipulation during manufacture of sausages. Since $S$. saprophyticus and $S$. epidermidis are opportunistic pathogens isolated from human urinary tract, they are not recommended for using as starter cultures.

The majority of strains identified as S. xylosus presented the typical characteristics of the species (Tables 1 and 2), such as nitrate reduction (88.8 $\%)$, acetoin production $(77.7 \%)$ and acid production from xylose $(77.7 \%)$ and mannose $(88.8 \%)$ but not from raffinose $(11.1 \%)$. Some strains identified as $S$. xylosus did not ferment xylose and mannose, as also reported by Drosinos et al. (2005) and Samelis et al. (1998). Few strains identified as $S$. saprophyticus were able to reduce nitrate $(33.3 \%)$ whereas $83.3 \%$ produced acetoin. Majority of strains identified as $S$. saprophyticus did not produce acid from mannose and xylose, but were able to ferment maltose and trehalose.

Table 1 - Biochemical tests for identification of Staphylococcus isolated from naturally fermented sausages.

\begin{tabular}{lcccccccc}
\hline Identification & Isolates & $\begin{array}{c}\text { Nitrate } \\
\text { Reduction }\end{array}$ & Urea & Acetoin & $\begin{array}{c}\text { Acetyl- } \\
\text { glucosamine }\end{array}$ & Arginine & Catalase Coagulase \\
\hline S. xylosus & $9(36)$ & $8(88,8)$ & $4(44,4)$ & $7(77,7)$ & $8(88,8)$ & $8(88,8)$ & $9(100)$ & 0 \\
S. saprophyticus & $6(24)$ & $2(33,3)$ & $5(83,3)$ & $5(83,3)$ & $4(66,6)$ & 0 & $6(100)$ & 0 \\
S. lentus & $4(16)$ & $3(75)$ & 0 & 0 & $4(100)$ & $1(25)$ & $4(100)$ & 0 \\
S. epidermidis & $1(4)$ & $1(100)$ & $1(100)$ & 0 & $1(100)$ & $1(100)$ & $1(100)$ & 0 \\
S. warneri & $1(4)$ & $1(100)$ & $1(100)$ & 0 & $1(100)$ & 0 & $1(100)$ & 0 \\
Doubtful profile & $3(12)$ & $2(66,6)$ & $1(33,3)$ & 0 & 0 & $2(66,6)$ & $3(100)$ & 0 \\
\hline
\end{tabular}

Values in parenthesis represent $\%$ of positive isolates.

Table 2 - Sugar fermentation profile of Staphylococcus isolated from naturally fermented sausages.

\begin{tabular}{lccccccccc}
\hline Identification & Glucose & Mannose & Maltose & Lactose & Trehalose & Mannitol & Xylose & Sucrose & Raffinose \\
\hline S. xylosus & $9(100)$ & $8(88,8)$ & $9(100)$ & $8(88,8)$ & $9(100)$ & $9(100)$ & $7(77,7)$ & $8(88,8)$ & $1(11,1)$ \\
S. saprophyticus & $6(100)$ & $3(50)$ & $6(100)$ & $5(83,3)$ & $6(100)$ & $4(66,6)$ & $1(16,6)$ & $6(100)$ & 0 \\
S. lentus & $4(100)$ & $4(100)$ & $4(100)$ & $4(100)$ & $4(100)$ & $4(100)$ & $3(75)$ & $4(100)$ & $4(100)$ \\
S. epidermidis & $1(100)$ & $1(100)$ & $1(100)$ & 0 & 0 & $1(100)$ & 0 & $1(100)$ & 0 \\
S. warneri & $1(100)$ & $1(100)$ & $1(100)$ & $1(100)$ & $1(100)$ & $1(100)$ & 0 & $1(100)$ & 0 \\
Doubtful profile & $3(100)$ & $2(66,6)$ & $3(100)$ & $1(33,3)$ & $2(66,6)$ & $3(100)$ & $1(33,3)$ & $2(66,6)$ & $1(33,3)$ \\
\hline
\end{tabular}

Values in parenthesis represent \% of positive isolates.

The selection of strains presenting desirable characteristics is necessary in order to achieve fermented sausages with appropriate technological and sensory properties. The first rule in selecting strains for using as starter cultures is nitrate reduction, as it influences the colour formation (Garcia-Verona et al., 2000). As secondary criteria, acetoin production and urease activity should be also evaluated. In the present work, strains identified as $S$. xylosus presented desirable characteristics also reported by Drosinos et al. (2005): nitrate reductase and urease activities and acetoin production. According to Smith and Palumbo (1983), tolerance to $\mathrm{NaCl}$ and $\mathrm{NaNO}_{2}$ and growth between 27 and $43^{\circ} \mathrm{C}$ are important characteristics. Strains tested in the present work 
showed positive catalase and negative coagulase activities, growth at 15 and $45^{\circ} \mathrm{C}$ and at two $\mathrm{NaCl}$ concentrations (10 and $15 \%)$ and $\mathrm{pH}$ values (5.0 and 5.5) in BHI broth (Table 3).

Table 3 - Characterization of Staphylococcus xylosus (BHI broth) isolated from naturally fermented sausages.

\begin{tabular}{|c|c|c|c|c|c|c|c|c|c|}
\hline & AB1 & AC3 & R1 & S4 & AD5 & AD1 & Q3 & M4 & U5 \\
\hline \multicolumn{10}{|l|}{$p H$} \\
\hline 5.5 & + & + & + & + & + & + & + & + & + \\
\hline 5.0 & + & + & + & + & + & + & + & + & + \\
\hline \multicolumn{10}{|c|}{ Temperature } \\
\hline $15^{0}$ & + & + & + & + & + & + & + & + & + \\
\hline $45^{0}$ & + & + & + & + & + & + & + & + & + \\
\hline \multicolumn{10}{|l|}{$\mathrm{NaCl}$} \\
\hline $10 \%$ & + & + & + & + & + & + & + & + & + \\
\hline $20 \%$ & + & + & + & + & + & + & + & + & + \\
\hline
\end{tabular}

+ represent positive growth.

Growth of strains was not inhibited on solid substrate (BHI agar) under different $\mathrm{NaCl}$ concentrations, showing tolerance to a concentration of $3 \%$ for this salt (Fig. 1). Strain AD1 showed the most accentuated decrease in growth, from $10^{8.7} \mathrm{CFU} / \mathrm{mL}$ to $10^{8} \mathrm{CFU} / \mathrm{mL}$. Seven out of nine strains tolerated a concentration of $200 \square \mathrm{g} / \mathrm{g}$ of $\mathrm{NaNO}_{2}$ and its growth was not changed in the absence of $\mathrm{NaNO}_{2}$ (Fig. 2).

Strains AB1 and AC3 showed a decrease in growth in presence of $200 \mu \mathrm{g} / \mathrm{g}$ of $\mathrm{NaNO}_{2}$, from $10^{8} \mathrm{CFU} / \mathrm{mL}$ to $10^{3} \mathrm{CFU} / \mathrm{mL}$. The same seven out of nine strains did not present differences in growth when $\mathrm{NaCl}$ and $\mathrm{NaNO}_{2}$ were used simultaneously, showing an appropriated tolerance (Fig. 3).

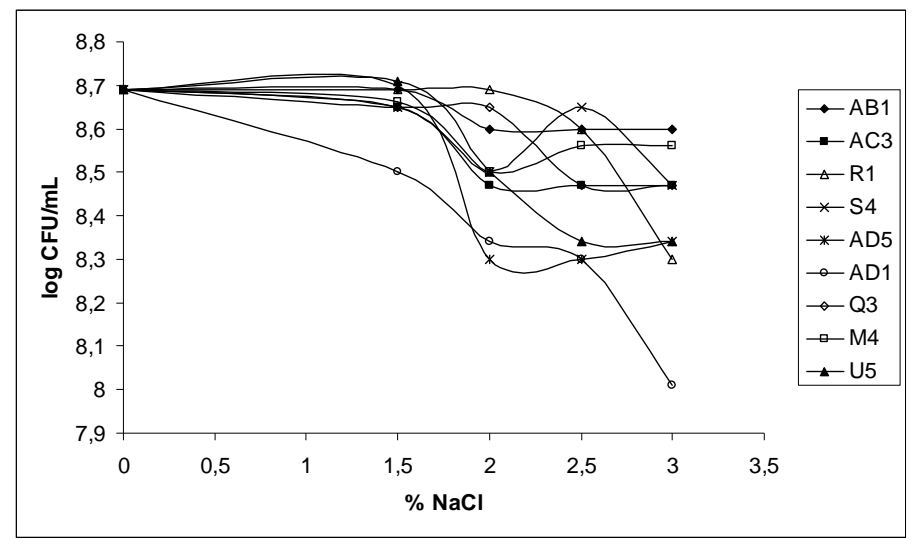

Figure 1 - Growth (log CFU/mL) of Staphylococcus xylosus strains isolated from naturally fermented sausages, in different concentrations of $\mathrm{NaCl}$. 


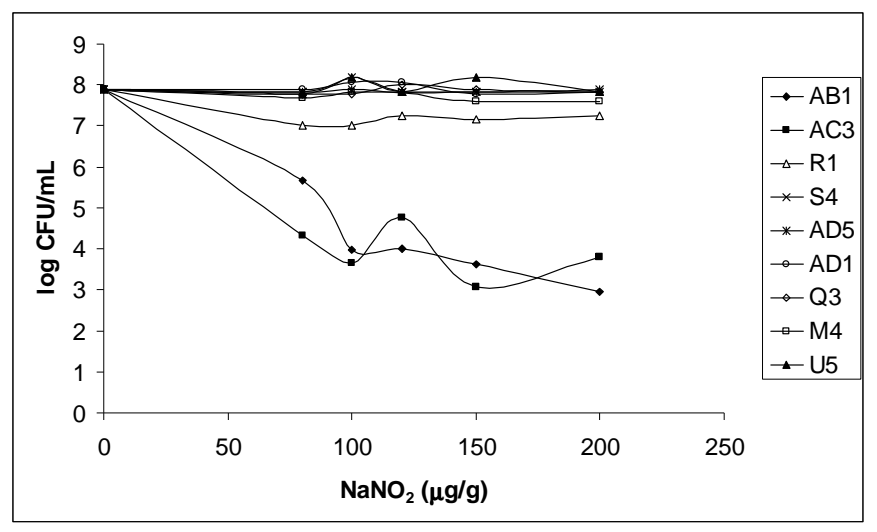

Figure 2 - Growth ( $\log \mathrm{CFU} / \mathrm{mL})$ of Staphylococcus xylosus strains isolated from naturally fermented sausages in different concentrations of $\mathrm{NaNO}_{2}$.

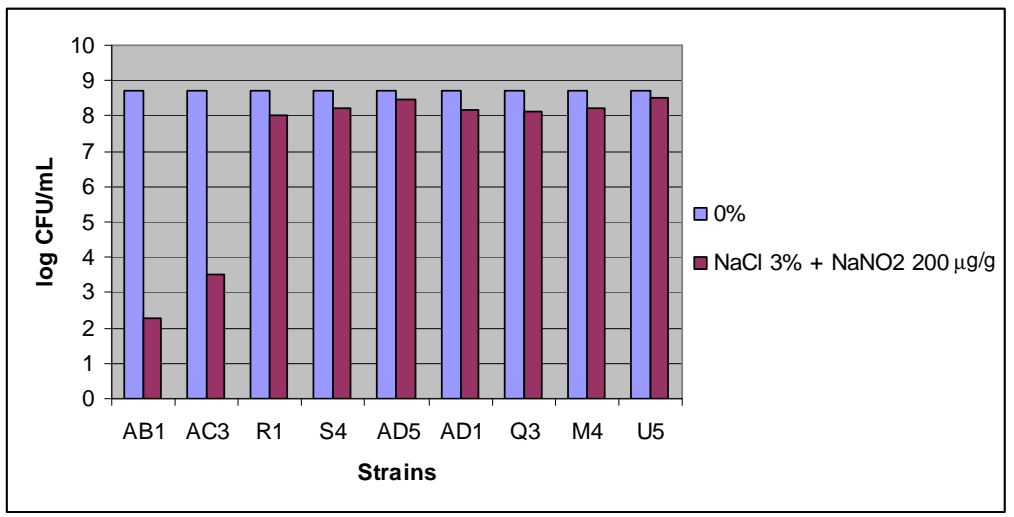

Figure 3 - Growth ( $\log$ CFU/mL) of Staphylococcus xylosus strains isolated from naturally fermented sausages, in broth added of $\mathrm{NaCl}$ and $\mathrm{NaNO}_{2}$.

The presence of curing salts, such as sodium nitrite and nitrate that improve the colour of the product, has an important bacteriostatic action against Clostridium botulinum and pathogenic microorganisms. Since as nitrite reduction ensures the colour formation in fermented sausages, it is necessary that the final product presents low levels of residual nitrites decreasing the risk of nitrosamine formation (Hugas and Monfort, 1997). The ability of starter cultures in reducing nitrites can be due to enzymatic activity of nitrite reductase or by lowering of $\mathrm{pH}$. Spectrophotometric measures did not present detectable levels of residual nitrites in tests carried out and control did not present change in $\mathrm{NaNO}_{2}$ initial concentration. Considering that $\mathrm{pH}$ was adjusted to 5.0 and nitrite reductase activity was not evaluated, apparently the nitrite reduction was carried out by $S$. xylosus strains.

S. xylosus also presented lipolytic and proteolytic activities (Hames and Hertel, 1998). In the present work, lipolytic activity was tested in the nine isolated strains and all of them showed lipolytic activity identified on plate assay, as an orange fluorescent halo under UV light (Table 4). Martín et al (2005) observed lipolytic activity in 99 out of 194 isolates of $S$. xylosus from slightly fermented sausages.

Table 4 - Lipolytic activity of Staphylococcus xylosus isolated from naturally fermented sausages.

\begin{tabular}{lccccccccc}
\hline Lypolitic & AB1 & AC3 & R1 & S4 & AD5 & AD1 & Q3 & M4 & U5 \\
Activity & + & + & + & + & + & + & + & + & + \\
\hline
\end{tabular}

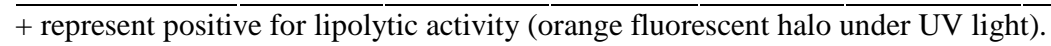




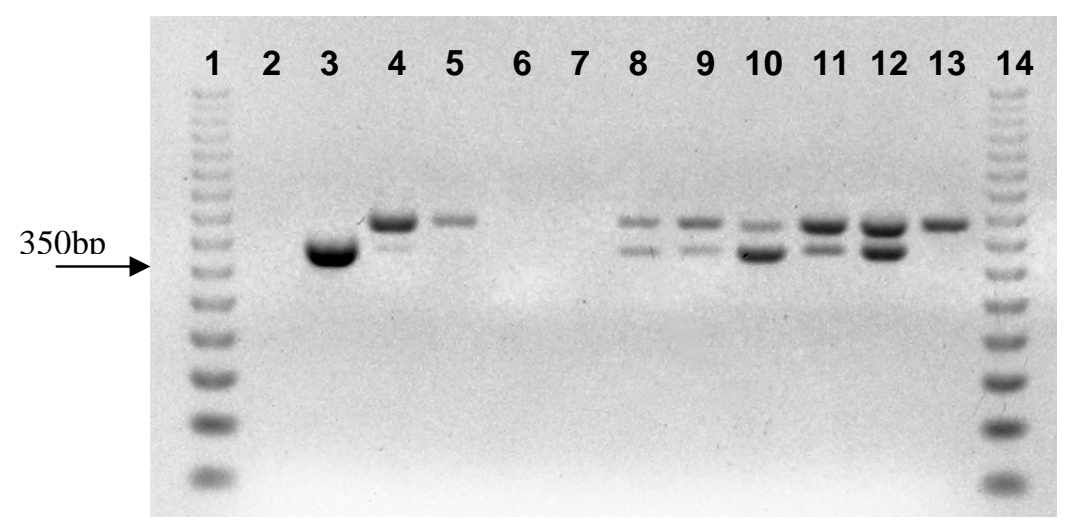

Figure 4 - PCR amplification with genus-specific primers TstaG422/Tstag765, using 50 ng of template DNA. Lanes 1 and 14: ladder 50 bp (Promega); lane 2: control (S. xylosus ATCC 29971); lane 3: control (water); lanes 4 - 13: wild strains of GCC+ isolated from naturally fermented sausages; lane 14: ladder $50 \mathrm{bp}$ (Promega).

In order to perform the molecular characterization of $S$. xylosus strains isolated from naturally fermented sausages, primers amplifying specific fragments of Staphylococcus genus and S. xylosus species were used. Nine strains identified as $S$. xylosus and one strain identified as S. epidermidis were selected for PCR analysis, as the identification by phenotypical methods has limitations and could result in misidentifications (Rhoden and Miller, 1995; Blaiotta et al., 2003, Morot-Bizot et al, 2006). Nine out of ten strains presented the expected fragment when primers
TstaG422/Tstag765 were used, confirming that the strains belonged to Staphylococcus genus (Fig. 4 and 5). Figure 4 shows a reaction in with $50 \mathrm{ng}$ of template DNA were used. As some strains did not present the expected fragment, the reaction was repeated with $2 \mu \mathrm{L}$ of template DNA without dilution (Fig. 5). Concentration of template DNA seemed to influence the reaction with primers TstaG422/Tstag765. Such influence was not observed in reactions where primers XYLF/XYLR were used (Fig. 6).

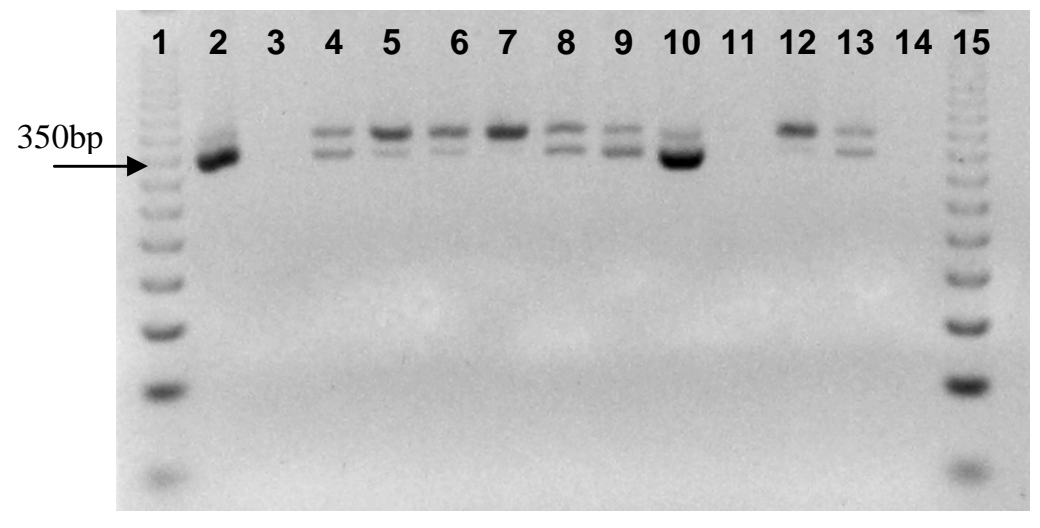

Figure 5 - PCR amplification with genus-specific primers TstaG422/Tstag765 using $2 \mu \mathrm{L}$ of template DNA (about $215 \mathrm{ng}$ ). Lanes 1 and 15: ladder $50 \mathrm{bp}$ (Promega); lane 2: positive control (S. xylosus ATCC 29971); lane 3: negative control (water); lanes 4 13: wild strains of GCC+ isolated from naturally fermented sausages; lane 14: negative control (L. plantarum ATCC). 
Only two strains confirmed to belong to $S$. xylosus species, as these were the only strains to give an expected PCR product of 539 bp when using $S$. xylosus species-specific primers (Fig. 6). The other strains did not present any fragment, suggesting that they belonged to other Staphylococcus species and were in disagreement with phenotypic characterization. Similar results were reported by
Morot-Bizot et al., (2003) where only 7 out of 27 strains isolated from food environments and identified as $S$. xylosus by API STAPH system, were identified to this species by specific PCR. In contrast, Di Maria et al. (2002) obtained agreement between phenotypic and genotypic characterization.

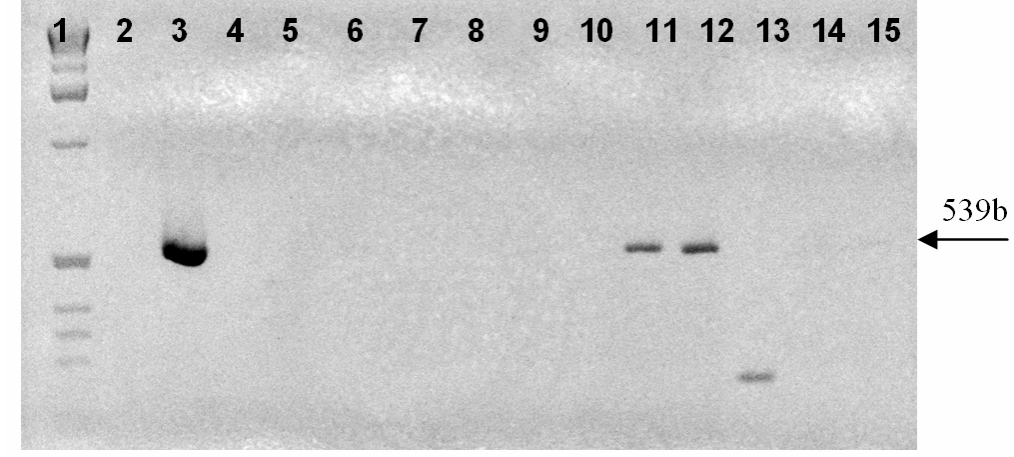

Figure 6 - PCR amplification with species-specific primers XYLF/XYLR. Lane 1: ladder $1 \mathrm{~kb}$ (Invitrogen); lane 2: negative control (water); lane 3: positive control (S. xylosus ATCC 29971); lanes 4 - 13: wild strains of GCC+ isolated from naturally fermented sausages.

\section{CONCLUSION}

These results demonstrated that molecular methods were significantly important for identification at species level, as it allowed an accurate identification of $S$. xylosus strains. The presence of this species among the indigenous flora of naturally fermented sausages produced in South Region of Brazil indicated its good adaptation capacity in this kind of product. The selected $S . \quad$ xylosus strains showed nitrate reductase, catalase and lipase activity, satisfactory growth in the presence of $\mathrm{NaCl}$ and $\mathrm{NaNO}_{2}$ and reducing nitrites ability, hence could be recommended as starter cultures and used in the production of fermented sausages.

\section{ACKNOWLEDGEMENTS}

This work was supported by EMBRAPA, Brazil.

\section{RESUMO}

Cepas de Micrococcaceae são aplicadas em embutidos cárneos fermentados como culturas iniciadoras, onde vários membros desta família são naturalmente encontrados. $\mathrm{O}$ objetivo deste trabalho foi isolar e caracterizar Staphylococcus xylosus de embutidos cárneos artesanais produzidos na região Sul do Brasil. Dos 89 isolados que apresentaram atividades positiva para catalase e negativa para coagulase, 25 cepas foram selecionadas para caracterização fenotípica. Nove cepas identificadas como Staphylococcus xylosus por API-STAPH foram avaliadas para capacidade de redução de nitratos e o crescimento satidfatório das cepas foi verificado na presença de nitrito e $\mathrm{NaCl}$, demonstrando seu potencial para utilização como culturas iniciadoras em embutidos cárneos fermentados. As cepas foram ainda avaliadas quanto ao gênero e espécie através da reação em cadeia da polimerase e apenas duas cepas foram identificadas como $S$. xylosus, diferindo dos resultados encontrados na caracterização fenotípica. 


\section{REFERENCES}

Aymerich, T., Martín, B., Garriga, M., and Hugas, M. (2003), Microbial Quality and Direct PCR Identification of Lactic Acid Bacteria and Nonpathogenic Staphylococci from Artisanal LowAcid Sausages. Appl Environ Microbiol, 698, 45834594.

Blaiotta, G., Pennacchia, C., Ercolini, D., Moschetti, G., Villani, F., (2003), Combining denaturing gradient gel electrophoresis of $16 \mathrm{~S}$ rDNAV3 region and $16 \mathrm{~S}$ $23 \mathrm{~S}$ rDNA spacer region polymorphism analyses for the identification of staphylococci from Italian fermented sausages. Syst Appl Microbiol, 26, 423433.

Cocolin, L., Manzano, M., Cantoni, C., Comi, G., (2001a), Denaturing gradient gel electrophoresis analysis of the 16s rRNA gene V1 region to monitor dynamic changes in the bacterial population during fermentation of Italian sausages. Appl Environ Microbiol, 67, 5113-5121.

Cocolin, L., Manzano, M., Aggio, D., Cantoni, C., Comi, G., (2001b), A novel polymerase chain reaction (PCR) - denaturing gradient gel electrophoresis (DGGE) for the identification of Micrococcaceae strains involved in meat fermentations. Its application to naturally fermented Italian sausages. Meat Science, 58, 59-64.

Coppola, S., Mauriello, G., Aponte, M., Moschetti, G., and Villani, F. (2000), Microbial succession during ripening of Naples-type salami a southern Italian fermented sausage. Meat Sci, 56, 321-329.

Corbiére Morot-Bizot, S., Talon, R., Leroy, S. (2004) Development of a multiplex PCR for the identification of Staphylococcus genus and four Staphylococcal species isolated from food. J Appl Microbiol, 97, 1087-1094.

Corbiére Morot-Bizot, S., Leroy, S., Talon, R. (2006), Staphylococcal community of a small unit manufacturing traditional dry fermented sausages. Int J Food Microbiol 108, 210-217.

Di Maria, S., Basso, A. L., Santoro, E., Grazia, L., and Coppola, R. (2002), Monitoring of Staphylococcus xylosus DSM 20266 added as starter during fermentation and ripening of sopressata molisana, a typical Italian sausage. J Appl Microbio, 92, 158-164.

Drosinos, E. H., Mataragas, M., Xiraphi, N., Moschonas, G., Gaitis, F. and Metaxopoulos, J. (2005), Characterization of the microbial flora from a traditional Greek fermented sausage. Meat Sci, 69, 307-317.

Garcia-Varona, M., Santos, E.M., Jaime, I., and Rovira, J. (2000), Characterization of Micrococcaceae isolated from different varieties of chorizo. Int J Food Microbiol, 54, 189-195.
Haba, E.; Bresco, O.; Ferrer, C.; Marqués, A.; Busquets, M.; Manresa (2000), A. Isolation of lipasesecreting bacteria by deploying used frying oil as selective substrate. Enzyme Microb Techno, 26, 4044.

Hammes, W. P. and Hertel, C. (1998). New developments in meat starters cultures. Meat Sci 49, 5125-5138.

Harrigan, W. F., McCance, M. E. (1976), Laboratory Methods in Food and Dairy Microbiology, Academic Press, London.

Hugas, M, and Monfort, I. Ma. (1997), Bacterial starter cultures for meat fermentation. Food Chem, 59, 547554.

Kotzekidou, P. (1992), Identification of Staphylococci and micrococci isolated from an intermediate moisture meat product. J Food Sci, 45, 837-839.

Kouker, G.; Jaeger, K. Specific and sensitive plate assay for bacterial lipases. (1987), Appl Environ Microbiol, 53, 211-213.

Martín, B., Garriga, M., Hugas, M., Bover-Cid, S., Veciana-Nogués, M. T., and Aymerich, T. (2005), Molecular, technological and safety characterization of Gram-positive catalase-positive cocci from slightly fermented sausages. Int J Food Microbio, 107, 148158.

Martineau, F., Picard, F. J., Ke, D., Paradis, S., Roy, P. H., Ouellette, M., Bergeron, M. G. (2001), Development of a PCR Assay for Identification of Staphylococci at Genus and Species Levels. J Clin Microbiol, 39, 2541-2547.

Miralles, M. C., Flores, J., and Perez-Martinez, G. (1996), Biochemical tests for the selection of Staphylococcus strains as potential meat starter cultures. Food Microbio, 13, 227-236.

Montel, M. C., Talon, R., Cantonnet, M. and Fournaud, J. (1992), Identification of Staphylococcus from French dry sausage. Lett Appl Microbiol, 15, 73-77.

Montel, M. C., Talon, R., Berdagué, J. L. and Rousset, S. (1996), Biochemical activities of Micrococcaceae and their effects on the aromatic profiles and odours of dry sausages model. Food Microbiol, 13, 489-499.

Morot- Bizot, S., Talon, R., and Leroy-Setrin, S. (2003), Development of specific PCR primers for a rapid and accurate identification of Staphylococcus xylosus, a species used in food fermentation. $J$ Microbiol Methods, 55, 279-286.

Morot- Bizot, S., Leroy, S., Talon, R. (2006), Staphylococcal community of a small unit manufacturing traditional fry fermented sausages. Int J Food Microbiol, 108, 210-217.

Papamoli, E., Kotzekidou, P., Tzanetakis, N. and Lipopoulou-Tzanetaki, E. (2002), Characterization of Micrococcaceae isolated from dry fermented sausage. Food Microbiol, 19, 441-449. 
Quere, F., Deschamps, A., and Urdaci, M.C. (1997), DNA prove and PCR-specific reaction for Lactobacillus plantarum. $J$ Appl Microbiol, 82, 783790.

Rantsiou, K., Iacumin, L., Cantoni, C., Comi, G., and Cocolin, L. (2005), Ecology and characterization by molecular methods of Staphylococcus species isolated from fresh sausages. Int J Food Microbiol, 97, 277-284.

Rhoden, D. L., Miller, J. M. (1995), Four-year prospective study of STAPH-IDENT system and conventional method for reference identification of Staphylococcus, Stomatococcus, and Micrococcus spp. J Clin Microbiol,33, 96-98.

Rossi, F., Tofalo, R., Torriani, S., Suzzi, G., (2001), Identification by $16 \mathrm{~S}-23 \mathrm{~S}$ rDNA intergenic region amplification, genotypic and phenotypic clustering of Staphylococcus xylosus strains from dry sausages. $J$ Appl Microbiol, 90, 365-371.

Samelis J., Metaxopoulos, J., Vlassi, M. and Pappa, A. (1998), Stability and safety of traditional Greek salami - a microbiological ecology study. Int J Food Microbio, 44, 69-82.

Seager, M. S., Banks, J. G., De Blackburn, C. W. and Board, R. G. (1986), A taxonomic study of Staphylococcus spp. isolated from fermented sausages. J Food Sci, 51, 295-297.
Smith, J. L. and Palumbo, S. A. (1983), Use of Starter Cultures in Meats. J Food Prot, 46, 997-1006.

Snopkova, S., Götz, F., Doskar, J., Rosypal, S., (1994), Pulse-field gel electrophoresis of the genomic restriction fragments of coagulase-negative staphylococci. FEMS Microbiol Lett, 124, 131-140.

Spricigo, C. B., Pianovsky, P. B. (2005) Effect of the use of curing salts and of a starter culture on the sensory and microbiological characteristics of homemade salamis. Braz Arch Biol Technol, 48, 169174.

Talon, R., Walter, D., Chartier, S., Barriere, C., Montel, M.C., (1999), Effect of nitrate and incubation conditions on the production of catalase and nitrate reductase by staphylococci. Int J Food Microbiol, 52, 47-56.

Talon, R., Leroy-Sétrin, S., Fadda, S., (2002), Bacterial starters involved in the quality of fermented meat products. In: Toldrá, F. (Ed.), Research Advances in Quality of Meat and Meat Products. Research Signpost, Trivandrum, India, pp. 175-191.

Received: December 16, 2005; Revised: February 23, 2007; Accepted: March 13, 2008. 